The diffusion of equity incentive plans in Italian listed companies: what is the trigger?

\author{
Alessandro Zattoni \\ Management Department \\ Parthenope University \\ $\&$ \\ Strategic and Entrepreneurial Department \\ SDA Bocconi \\ Viale Isonzo 23 \\ 20136 Milano \\ Tel: $0039-02-58362532$ \\ Fax: $0039-02-58362530$ \\ alessandro.zattoni@unibocconi.it \\ $\&$ \\ Alessandro Minichilli \\ Strategic and Entrepreneurial Department \\ Bocconi University \\ Viale Isonzo 23 \\ 20136 Milano \\ Tel: $0039-02-58362543$ \\ Fax: 0039 - 02- 58362530 \\ alessandro.minichilli@unibocconi.it
}




\title{
The Diffusion of Equity Incentive Plans in Italian Listed Companies: What
} is the Trigger?

\begin{abstract}
Manuscript type: Empirical

Research question: Recent dynamics in the institutional and market environment facilitated the propagation of equity incentive plans outside the US and the UK. This study sheds light on the reasons behind the diffusion of these plans in a country, Italy, where companies are usually controlled by a blockholder and these instruments were almost absent.

Research findings: To gain a deep understanding of the phenomenon, we collected data on both the diffusion and the technical aspects of equity incentive plans adopted by Italian listed companies in 1999 and 2005. The results show that (i) the determinant of their adoption is the firm size rather than the absence of a controlling shareholder; (ii) these plans are not extensively used to extract company value, although few cases suggest this possibility; and (iii) plans' characteristics generally comply with the requirements in tax law so that fiscal benefits can be accessed.
\end{abstract}

Theoretical/Academic implications: Our findings contribute to expand the traditional knowledge on reasons behind the adoption of equity incentive plans outside Anglo-Saxon countries. Further, they provide support for a symbolic perspective of corporate governance, according to which the introduction of new governance practices may not imply substantive governance reforms.

Practitioner/Policy implications: Our study recommends policymakers to improve the disclosure rules about these plans, and to avoid the introduction of fiscal benefits that incentive the diffusion of some compensation schemes respect to others. Moreover, our results encourage members of remuneration committees to pay attention to specific characteristics of the plans. 
Keywords: Corporate Governance, Equity Incentive Plans, Diffusion of Governance Practices, Italy. 


\section{The diffusion of equity incentive plans in Italian listed companies: what is the trigger?}

\section{INTRODUCTION}

Past studies have brought to light the dissimilarities in the pay packages of managers in Anglo-Saxon countries as compared to other nations (e.g. Bebchuk, Fried, and Walker, 2002; Cheffins and Thomas, 2004; Zattoni, 2007). In the UK and, above all, in the US remuneration encompasses a variety of components, and short and long term variable pay carries more weight than elsewhere (Conyon and Murphy, 2000). In other countries, however, fixed wages have always been the main ingredient in top managers' pay schemes. Over time, variable short term pay has become more substantial, and the impact of fringe benefits has gradually grown. Notwithstanding, incentives linked to reaching medium to long term company goals have never been widely used (Towers Perrin, 2000).

In recent years, however, pay packages of managers have undergone an appreciable change as variable pay has increased considerably, even outside the US and the UK. In particular, managers in most countries have experienced an increase in the variable pay related to long term goals. Within the context of this general trend toward medium and long term incentives, there is a pronounced tendency to adopt plans involving stocks or stock options (Towers Perrin, 2000 and 2005). The drivers of the diffusion of long term incentive plans seem to be some recent changes in the institutional and market environment at local and global level. Particularly important triggers of the convergence towards the US pay paradigm are both market oriented drivers such as the evolving share ownership patterns or the internationalization of the labor market, and law-oriented drivers such as corporate or tax regulation (Cheffins and Thomas, 2004). Driven by these changes in the institutional and market environment, we observe a global trend toward the "Americanization of international 
pay practices”, characterized by high incentives and very lucrative compensation mechanisms (e.g. Cheffins, 2003; Cheffins and Thomas, 2004).

Ironically, the spread of the US pay paradigm around the world happens when it is hotly debated at home. In particular, the critics concern both the level of executive compensation packages, and the use of equity incentive plans (Cheffins and Thomas, 2004). Critics stressed that US top managers, and particularly the CEOs, receive very lucrative compensation packages. The '80s and '90s saw an increasing disparity between CEO's pay and that of rankand-file workers. Thanks to this effect, their direct compensation has become hundred times that of an average employee (Hall and Liebman, 1998). The main determinants of the increasing level of CEOs' and executives' compensation are annual bonuses and, above all, stock option grants (Conyon and Murphy, 2000). Stock option plans have been recently criticized by scholars and public opinion because their characteristics are too generous and symptomatic of a managerial extraction of the firm's value (Bebchuk et al., 2002; Bebchuk and Fried, 2006).

In light of these recent events and of the increased tendency to adopt equity incentive plans, this paper aims at understanding the reasons behind the dissemination of stock option and stock granting plans outside the US and the UK ${ }^{\mathrm{i}}$. The choice to investigate this phenomenon in Italy relies on the following arguments. First, the large majority of previous studies analyze the evolution of executive compensation and equity incentive plans in the US and, to a smaller extent, in the UK. Second, ownership structure and governance practices in continental European countries are substantially different from the ones in Anglo-Saxon countries. Third, continental European countries, and Italy in particular, almost ignored the use of these instruments until the end of the ' 90 s.

Our aim is to compare the explanatory power of three competing views on the diffusion of equity incentive plans: (i) the optimal contracting view, which states that compensation 
packages are designed to minimize agency costs between managers and shareholders (Jensen and Murphy, 1990); (ii) the rent extraction view, which states that powerful insiders may influence the pay process for their own benefit (Bebchuk et al., 2002); and (iii) the perceivedcost view (Hall and Murphy, 2003), which states that companies may favor some compensation schemes for their (supposed or real) cost advantages.

To this purpose, we made an empirical study on the reasons why Italian listed companies adopted equity incentive plans since the end of the '90s. To gain a deep understanding of the phenomenon, we collected data and information both on the evolution of national institutional environment in the last decade, and on the diffusion and the characteristics (i.e. technical aspects and objectives) of equity incentive plans adopted by Italian listed companies in 1999 and 2005. We used both logit models and difference-ofmeans statistical techniques to analyze data. Our results show that (i) firm size, and not its ownership structure, is a determinant of the adoption of these instruments; (ii) these plans are not extensively used to extract company value, although few cases suggest this possibility; and (iii) plans' characteristics are coherent with the ones defined by tax law to receive special fiscal treatment.

Our findings contribute developing the literature on both the rationales behind the spreading of equity incentive schemes, and the diffusion of new governance practices. They show, in fact, that equity incentive plans have been primarily adopted to take profit of large tax benefits, and that in some occasions they may have been used by controlling shareholders to extract company value at the expense of minority shareholders. In other words, our findings suggest that Italian listed companies adopted equity incentive plans to perform a subtle form of decoupling. On the one hand, they declared that plans were aimed to align shareholders' and managers' interests, and incentive value creation. On the other hand, thanks to the lack of transparency and previous knowledge about these instruments, companies used these 
mechanisms to take advantage of tax benefits, and sometimes also to distribute a large amount of value to some powerful subjects. These results support a symbolic perspective on corporate governance, according to which the introduction of equity incentive plans please stakeholders - for their implicit alignment of interests and incentive to value creation - without implying a substantive improvement of governance practices.

\section{THEORETICAL BACKGROUND}

\section{Corporate governance in Italian listed companies}

Italian companies are traditionally controlled by a large blockholder (Zattoni, 1999). Banks and other financial institutions do not own large shareholdings and do not exert a significant influence on governance of large companies, at least as far as they are able to repay their financial debt (Bianchi, Bianco, and Enriques, 2001). Institutional investors usually play a marginal role because of their limited shareholding, their strict connections with Italian banks, and a regulatory environment that does not incentive their activism. Finally, the stock market is relatively small and undeveloped, and the market for corporate control is almost absent (Bianco, 2001). In short, the Italian governance system can be described as a system of 'weak managers, strong blockholders and unprotected minority shareholders’' (Melis, 2000: 354).

The board of directors is traditionally one tier, but shareholders' general meeting must appoint also a board of statutory auditors whose main task is to monitor directors' performance (Melis, 2000). Further, some researches published in the '90s showed that the board of directors was under the relevant influence of large blockholders. Both inside and outside directors were in fact related to controlling shareholders by family or business ties (Melis, 1999 and 2000; Molteni, 1997).

Coherently with this picture, fixed wages have been the main ingredient of top managers' remuneration and incentive schemes linked to reaching medium to long term 
company goals have never been widely used (Melis, 1999). Equity incentives schemes adopted by Italian companies issue stocks to all employees unconditionally for the purpose of improving company atmosphere and stabilizing the share value on the Stock Exchange. Only very few can be compared to stock options plans in the true sense of the term. Even in this case, however, directors and top managers were rarely evaluated through stock returns, because of the supposed limited ability of the Italian stock market to measure firm's performance (Melis, 1999).

\section{The evolution of Italian institutional context in the last decade}

The institutional context in Italy has evolved radically in the last decade, creating the possibility for the dissemination of equity incentive plans. The main changes regarded the development of commercial law, the introduction and the update of the code of good governance, the issue of some reports encouraging the use of equity incentive plans, and the evolution of the tax law (Zattoni, 2006).

Concerning the national law and regulations, some reforms in the commercial law (1998, 2003 and 2005) and the introduction (1999) and update (2002) of the national code of good governance contributed to improve the corporate governance of listed companies (Zattoni, 2006). Financial markets and corporate law reforms improved the efficiency of the Stock Exchange and created an institutional environment more favorable to institutional investors' activism (Bianchi and Enriques, 2005). At the same time the introduction and update of the code of good governance contributed to improve governance practices at board level. These reforms did not produce an immediate effect on governance practices of Italian listed companies, although they contributed to improve, slowly and with some delay, their governance standards (Zattoni, 2006). 
Beyond the evolution of governance practices, some changes in the institutional environment affected directly the diffusion and the characteristics of equity incentive plans. Both the white paper of the Ministry of the Industry and Foreign Commerce and the code of good governance issued by the national Stock Exchange invited companies to implement equity incentive plans in order to develop a value creation culture in Italian companies ${ }^{\mathrm{i}}$. Furthermore, in 1997 fiscal regulations were enacted allowing tax exemption on the shares received through an equity incentive plan. According to the new regulation, which took effect on 1 January 1998, issuance of new stocks to employees by an employer or another company belonging to the same group did not represent compensation in kind for income tax purposes (Autuori, 2001). In the following years, the evolution of tax rules reduced the generous benefits associated with the use of equity incentive plans, but also the new rules continued to favor the dissemination of these plans ${ }^{\mathrm{iii}}$.

Driven by these changes in the institutional context, equity incentive plans became widely diffused among Italian listed companies at the end of the '90s (Zattoni, 2006). Ironically, the diffusion of these instruments - in Italy and in other countries such as Germany (Bernhardt, 1999), Spain (Alvarez Perez and Neira Fontela, 2005), and Japan (Nagaoka, 2005) - took place when they were strongly debated in the US for their unpredicted consequences and the malpractices associated with their use (Bebchuk et al., 2002).

\section{The rationales explaining the adoption of equity incentive plans}

Equity incentive plans are a main component of executive compensation in the US. Their use is mostly founded on the argument that they give managers an incentive to act in the shareholders' interests by providing a direct link between their compensation and firm stockprice performance (Jensen and Murphy, 1990). Beyond that, equity incentive plans have also other positive features, as they may contribute to attract and retain highly motivated 
employees, to encourage beneficiaries to risk taking, and to reduce direct cash expenses for executive compensation (Hall and Murphy, 2003).

Despite all their positive features, the use of equity incentive plans is increasingly debated in the US. In particular, critics question their presumed effectiveness in guaranteeing the alignment of executives' and shareholders' interests. They point out that these instruments may be adopted to fulfill other objectives, such as to extract value at shareholders expenses (e.g. Bebchuck and Fried, 2006), or even to achieve a (real or perceived) reduction in compensation costs (e.g. Murphy, 2002). In synthesis, the actual debate indicates that three different rationales may explain the dissemination and the specific features of equity incentive plans: a) the optimal contracting view (Jensen and Murphy, 1990); b) the rent extraction view (Bebchuk et al., 2002); and c) the perceived-cost view (Hall and Murphy, 2003).

According to the optimal contracting view, executive compensation packages are designed to minimize agency costs between top managers (agents) and shareholders (principals) (Jensen and Meckling, 1976). The boards of directors are effective governance mechanisms aimed at maximizing shareholders value and the top management's compensation scheme is designed to serve this objective (Fama and Jensen, 1983). Providing managers with equity incentive plans may mitigate managerial self-interest by aligning the interests of managers and shareholders (Jensen and Meckling, 1976). Following the alignment rationale, equity incentives may improve firm performance, as managers are supposed to work for their own and shareholders' benefit (Jensen and Murphy, 1990). In short, these instruments are designed to align the interests of managers with those of shareholders, and to motivate the former to pursue the creation of share value (Jensen and Murphy, 1990).

Agency costs are high when there is a separation between ownership and control (Berle and Means, 1932). Dispersed shareholding and the absence of large blockholders force shareholders to delegate decision making to top managers, and drastically reduce 
shareholders' incentives and ability to effectively monitor their behaviors (e.g. Hart, 1995; Shleifer and Visnhy, 1997) ${ }^{\mathrm{iv}}$. In these circumstances, the risks of management's abuse increase and the adoption of equity incentive plans may contribute to align top managers' and shareholders' interests (Jensen and Murphy, 1990; Shleifer and Visnhy, 1997). When ownership structure is concentrated, the controlling shareholders may though nominee themselves or appoint their own nominees as members of the board of directors (e.g. Melis, 1999). Consequently, managers are restricted in the pursuit of their personal objectives to the detriment of shareholders, and there is not a strong need to use equity incentive plans to align managers' and shareholders' interests (Zattoni, 2007). In this situation, in fact, agency costs can be effectively reduced by using tools other than incentive schemes. Therefore, following the optimal contracting view we would expect the next relationship to hold:

Hypothesis 1: companies with no controlling shareholder will adopt equity incentive plans more often than companies with a controlling shareholder.

According to the rent extraction (or managerial-power) view, powerful insiders may influence the pay process for their own gain at the expense of shareholders (Bebchuk and Fried, 2006). According to this view, rent extraction is facilitated by ineffective corporate boards, in which outside directors act under the influence of powerful executives, are often sympathetic to managers, or are simply ineffectual in overseeing compensation practices (Bebchuk et al., 2002). As a result, boards do not implement optimal compensation packages, and top managers receive pay in excess (i.e. a rent) of the level that would be optimal for shareholders. Market forces are hardly strong enough to limit this behavior; they instead provide incentives for structuring compensation packages in a way that camouflages the presence and the extent of rent extraction (Bebchuk et al., 2002). There are several 
characteristics of these instruments that seem to be coherent with this view: the lack of adjustments for industry and market returns, the uniform use of at-the-money options, the lack of lock-up mechanisms, and so on (Bebchuk et al., 2002).

While in the US and the UK top managers are the most powerful insiders, in Italy (and in many other continental European countries) large blockholders play such role (Barca and Becht, 2001). Controlling shareholders may nominee themselves, or their relatives, as directors and top managers of their companies (e.g. Melis, 1999; Molteni, 1997), and have the power to influence the board decision making (Melis, 1999 and 2000). Thanks to their power as owners, directors and (sometimes also) managers, controlling shareholders may extract private benefits of control at minority shareholders' expense (La Porta, Lopez-de-Silanes, and Shleifer, 1999). To this purpose, they may use different techniques such as (i) increasing their compensation as managers and directors; (ii) using corporate assets for personal purposes; (iii) transferring wealth from operating companies to holding companies through the intergroup exchanges of goods, services and financial resources; (iv) exploiting business opportunities through another company they own; and so on (Johnson, La Porta, Lopez-deSilanes, and Shleifer, 2000). Some studies showed that private benefits of control are particularly high in Italy, supporting the view that controlling shareholders of Italian listed companies may extract a large amount of value at the minority shareholders' expenses (e.g. Nenova, 2003; Dyck and Zingales, 2004).

Equity incentive plans are instruments that may be particularly effective to extract value from the company. They allow, in fact, controlling shareholders to transfer a large amount of money camouflaging the sum at the grant date, and to hide the extraction of value because these plans are perceived as instruments aimed at solving governance problems and fostering value creation (e.g. Bebchuk et al., 2002). To reach this purpose, controlling shareholders may design very generous plans targeted to them as top managers or directors of the 
corporation. Generous plans are that ones with (i) a strike price lower than the market value, (ii) no relationship with company's performance, and (iii) no lock-up provisions (Bebchuk and Fried, 2006; Bebchuk, et al., 2002). Thus, following the rent extraction view we would expect the next relationship to hold:

Hypothesis 2: the equity incentive plans targeted to top managers or directors will differ from plans offered to a large number of employees. In particular, plans targeted to top managers and directors will have more often (i) a strike price lower that the market value; (ii) no relationship with company's performance; and (iii) no lock-up provisions.

According to the perceived-cost view, the popularity of equity incentive plans largely reflects their favorable tax and accounting treatments (Murphy, 2002). Boards of directors are convinced that equity incentives are cheap to grant because, until few years ago, there were no accounting costs and no cash outlays. Moreover, under U.S. accounting and tax rules in vigor before the introduction of SFAS 123R, when the option was exercised, accounting income was unchanged and taxable income reduced (Murphy, 2002). Even if the value of these plans is disclosed in footnotes to the annual report and financial markets are (reasonably) efficient, managers consider only the accounting consequences of alternative compensation tools (Hall and Murphy, 2003). The favorable accounting and tax treatments make the perceived cost of an option much lower than the economic costs. The large diffusion of broad-based plans and the development of plans that conform to the evolution of accounting and tax regulations seem to support this view (Murphy, 2002).

Summing up, following the perceived-cost view equity incentives may be utilized by companies to cushion the impact of labor costs on profit and loss accounts (Hall and Murphy, 
2003). In the period investigated in the study, the law in force in Italy did not imply an accounting cost on these plans. Furthermore, accounting practices have been changed only at the end of the period, and for this reason they did not have a relevant effect on explaining the diffusion and the characteristics of plans in this time frame. On the other hand, the tax regulation changed substantially with a potential effect on the characteristics of plans. In particular, according to the tax law in force between 1998 and 1999, the tax benefits were valid only if the operation involved (i) employees of the company, and not its directors, and (ii) newly issued shares, and not firm's shares purchased on the market. Furthermore, tax law did not impose any requirement about the level of the strike price. The tax law in force after 2000 changed the rules to tap into tax benefits: (i) including plans targeted to directors; (ii) extending benefits to operations which involve buying previously issued stocks; and (iii) imposing that options or shares were offered at least at market value. So, following the perceived-cost view we would expect the next relationship to hold:

Hypothesis 3: equity incentive plans issued in Italy in the period 2004-2005 will differ from plans issued in the period 1998-1999. In particular, plans issued in 2004-2005 will be characterized by (i) the larger participation of directors; (ii) the larger use of previously issued shares; and (iii) the larger adoption of an exercise price offered at market value.

\section{METHODS}

\section{Sample and data collection}

Our sample includes all Italian listed companies at the end of 1999 and 2005. At the end of 1999 there were 238 Italian listed companies. The number of listed companies in the Italian Stock exchange increased in the period between 2000 and 2005, because there were 12 
companies going public in excess of cancellations and de-listings. So, at the end of 2005 there were 250 Italian listed companies.

We collected information both on the companies and the plans. For each listed company we collected market capitalization (in million euros), industry classification adopted by the Stock Exchange (manufacturing, services, and financial industries), direct ownership structure (name of first shareholder and its shareholding), ultimate ownership structure (checking if the ultimate controlling shareholder was a family or the State), presence of a syndicate agreement among shareholders, and number of plans implemented. This information was collected from reports of the Italian Stock Exchange and Consob (the Italian financial market regulator), and from companies’ annual reports.

The synthetic profile of Italian listed companies at the end of 1999 and 2005 is presented in table 1 . The table shows that (i) Italian listed firms are more represented in manufacturing and financial industries in 1999, while they are more evenly distributed in 2005; (ii) a large number of companies is under the influence of a controlling shareholder that is usually represented by a family; (iii) a large number of companies went public in the period investigated; (iv) 60 companies issued equity incentive plans in 1998-1999 and 57 companies adopted these instruments in 2004-2005.

\section{Insert table 1 about here}

The information on the features of equity incentive plans was collected from companies' annual reports for the years 1999 and 2005. We focused on plans issued in the two preceding years (1998-1999 and 2004-2005) to collect enough information on each plan. This information was independently codified and analyzed by both scholars. Specifically, for each plan an attempt was made to reconstruct: 1) the date the plan was approved; 2) the 
content of the offer: options or shares; 3) the recipients' categories: employees, managers, directors, or other categories; 4) the technical methods utilized: the issue of new shares or the purchase of own shares on the market; 5) the price of issuance on stock, or the exercise price on options: at market level or below market level; 6) if the plan included some conditions to compensate recipients: characteristics of recipients or company's economic or financial performance; 7) the goal that inspired the plan: incentive and align, attract and retain, foster the employees' identity; 8) the time horizon: vesting and exercise period; 9) the number of beneficiaries; 10) the presence of lock-up provisions. We used characteristics of equity incentive plans both to discriminate plans issued in different periods or targeted to different recipients, and to analyze their differences with t-test for difference of means.

By opting to focus on listed firms, it was possible to reconstruct the main characteristics of equity incentive plans. However, the data-gathering process drew attention to certain problems that were difficult to overcome. First, information from corporate annual reports varied greatly in terms of scope and detail. In particular, while some firms gave a rather analytical description of the main features of their incentive plans, others simply stated that equity incentives were granted to some key personnel in the group. Second, some firms made no mention of these instruments in the annual report. Nonetheless, it was clear from notes to the financial statement that directors of such firms actually held options to purchase or subscribe company shares. This was usually the case when the plan was approved in fiscal years prior to the financial statement in question. To compensate for the lack of data, at least in part, additional information was collected from annual reports of the previous year. This second phase of data collection allowed us to find more in-depth information on the features of the plans. However, the reticence of the firms in question prevented us from reconstructing a complete profile on every plan in the study. Unfortunately, companies almost never 
provided the fair value of the options (even in 2005) and rarely indicated the number of options and of recipients.

Finally, to capture a more complete and contextual portrayal of the phenomenon under study, we collected more information on the diffusion and the characteristics of equity incentive plans adopted by Italian listed companies through different sources (specialized press - including the leading Italian economic newspaper, Il Sole 24 Ore - top management magazines, other articles and books). We used triangulation to examine the phenomenon from multiple perspectives, and to enrich our understanding of the object under investigation (Jick, 1979). The supplementary evidence collected on the diffusion and characteristics of equity incentive plans played a relevant role in the investigation of cases of rent extraction. It is, in fact, difficult to find out traces of misbehavior through the analysis of annual reports. First, controlling shareholders wanting to extract company's value at minority shareholders' expenses would like to hide their opportunistic behavior to avoid sanctions. Second, the accounting and disclosure rules in vigor at that time could allow these subjects to hide the transfer of money from the company to their pocket.

\section{Measures and data analysis of logit model}

We used a logistic regression to investigate the relationship between the firm ownership structure and the use of equity incentive plans. In the statistical model, the dependent variable was the use of equity incentive plans, and the independent variable was the absence of a controlling shareholder, i.e. no shareholder has more than 30 per cent of firm's shares (1=no controlling shareholder, $0=$ otherwise).

The absence of a controlling shareholder. The threshold of 30 per cent is used to identify the presence or absence of a controlling shareholder. Despite previous international studies considered a threshold of about ten or twenty per cent (e.g. La Porta et al., 1999; 
Faccio and Lang, 2002), in this study we decided to adopt a higher threshold, equals to 30 per cent. We believe that the thresholds of ten or twenty per cent of shares are particularly suitable to investigate the presence of blockholders in the Anglo Saxon capitalism, where companies' shareholding is more dispersed. These thresholds are not adequate to measure ownership structure in Continental Europe, where main shareholders own on average more than 30 per cent of company’s shares (e.g. Barca and Becht, 2001). Moreover, the threshold of 30 per cent is particularly relevant because each subject overcoming this threshold is obliged to launch a takeover on all company's share. According to legal rules on takeovers, listed companies are considered contestable if the largest shareholding is lower than 30 per cent (Mosca and Angelillis, 2008).

As control variables we considered (i) the identity of the ultimate owner (family or the State), (ii) the presence of syndicate agreements, (iii) the firm industry, (iv) the log market capitalization, (v) the listing in the previous five years, (vi) the presence of plans in 19981999.

The identity of the ultimate owner. We controlled for identity of two ultimate shareholders: families ( $1=$ yes, $0=$ otherwise) and the State $(1=$ yes, $0=$ otherwise). Families are the dominant shareholder of a large number of Italian listed companies (Zattoni, 2006). Furthermore, as indicated by hypotheses 2 , families may be tempted to use these mechanisms to extract value from the company at minority shareholders' expenses. We controlled also for the State because previous studies on the diffusion of equity incentive plans in Italy showed that, in the past, State-owned companies used these instruments (Cesarini, 1986). The identity and the shareholding of the ultimate owner were collected through the Consob database.

The presence of a syndicate agreement. We controlled also for the presence of syndicate agreements ( $1=$ yes, and $0=$ otherwise) because they are an important characteristic of the ownership structure of Italian listed companies. Such agreements are used to reinforce 
alliances among shareholders and are divided in two categories: voting syndicate agreements and blocking syndicate agreements (Gianfrate, 2007).

The firm industry. We controlled also for industry as previous studies on Italian companies showed that equity incentive plans were more diffused among financial companies (Gualtieri, 1993). The rationale is that these companies have a more sophisticated financial culture and a longer tradition in the use of incentives related to financial performances. We measured the firm's industry creating dummy variables for each category of the Stock Exchange: manufacturing, service, and financial companies.

The log market capitalization. We controlled for firm size because it is supposed to positively affect the adoption of equity incentive plans. First, in large companies is more difficult to monitor management (Eaton and Rosen, 1983). Second, large companies have superior abilities of introducing governance devices as equity incentives because they usually have staff specialized in accounting, taxation and commercial law (Uchida, 2006). The market capitalization is measured in million euros at the end of 1999 and 2005. We then calculated its logarithm to control for heteroskedasticity.

The listing in the five previous years. This variable is a dummy variable measuring if the company went public in the five previous years (1=yes, $0=$ otherwise). We controlled for this variable because companies going public usually adopt equity incentive plans to increase the IPO's probability of success and to incentive management to value creation (Certo, Daily, Cannella, and Dalton, 2003).

The presence of plans in 1998-1999. This variable measures if the company issued a plan in the previous period investigated in the study ( $1=$ yes, $0=$ otherwise). We introduced this variable because companies that have already adopted a plan are more likely to adopt plans in the future. 


\section{Measures and data analysis of t-test for difference of means}

To compare the characteristics of equity incentive plans targeted to top managers and directors with plans targeted to a larger number of employees we used t-test for difference-ofmeans. To this purpose, we used multiple levels of discrimination: (i) plans offered to less than 3 employees versus all other plans, (ii) plans offered to less than 10 employees versus all other plans, (iii) plans offered to directors versus all other plans. The thresholds of 3 and 10 employees are aimed at capturing the lower and the upper limits of top management team's size, as indicated by Hambrick (2005).

Moreover, to understand if the tax law may be a driver of equity incentive plans we divided plans in two groups according to their date of approval: (i) plans issued in 1998-1999, and (ii) plans issued in 2004-2005. We then used t-test for difference-of-means to compare the characteristics of equity incentive plans issued in the two periods that, as we have seen, are characterized by different tax rules.

\section{RESULTS}

\section{Equity incentives plans and ownership structure}

Table 2 shows the results of the analysis of the influence of ownership structure (absence of a controlling shareholder, ultimate shareholder as a family or the State, presence of a syndicate agreement), industry (service and finance), size (log market capitalization), and listing in the five previous years on the likelihood of adoption of equity incentive plans both in 1998-1999 and 2004-2005. For 2004-2005 we controlled also for companies with plans issued in 19981999.

The logit models - see table 2 - reveal that equity incentive plans are significantly more likely in companies with larger capitalization ( $\mathrm{p}<.001$ in $98-99$ and $\mathrm{p}<.01$ in 04-05), and companies listed in the five previous years $(\mathrm{p}<.05$ in $04-05)$, while they are less common in 
companies in the finance industry $(\mathrm{p}<.05 \text { in } 98-99)^{\mathrm{v}}$. Our results emphasize that firm size is the most important antecedent of equity incentive plans' adoption, while ownership structure does not have a significant impact on the use of these instruments. In sum, our findings do not support hypothesis 1 .

Insert table 2 about here

\section{Equity incentive plans and rent extraction}

We tested the differences between plans offered to top managers and directors and the ones offered to employees. The results do not support the existence of a significant difference between different groups of plans (see table 3, 4 and 5). In particular, our results show that the plans offered to less than 3 employees involve more often stock options (options $=1.00$ versus .84, $\mathrm{p}<.001$ ) and less often stocks (shares $=.00$ versus $.17, \mathrm{p}<.001$ ). Moreover, plans offered to less than 3 and less than 10 employees have a stronger connection with company's results (company $=1.00$ versus .68, $\mathrm{p}<.001$ ), are less used to improve the employee's identification with the company (identity $=.00$ versus $.11, \mathrm{p}<.01$ ), and do not have lock up provisions (lock-up $=.00$ versus $.83, \mathrm{p}<001$ ). Finally, plans offered to directors involve more often stock options (options $=.96$ versus $.81, \mathrm{p}<.05$ ) and less often stocks (shares $=.04$ versus $.20, \mathrm{p}<.05$ ), use less often a capital increase (capital increase $=.74$ versus $.91, \mathrm{p}<.01$ ) and more often already issued shares (sell own shares $=.26$ versus $.10, \mathrm{p}<.01$ ), have more often an exercise price at market value (market value $=.80$ versus $.44, \mathrm{p}<.001$ ) and less often a market price lower than the market price (lower than market value $=.20$ versus $.56, \mathrm{p}<.001$ ), and have a stronger connection with company’s results (company $=.91$ versus .64, $\mathrm{p}<.05$ ).

These results indicate that the characteristics of equity incentive plans issued by Italian listed companies do not significantly differ between elite and broad based plans. More in 
depth, plans issued to few employees or directors do not have a lower strike price and are connected more often with company's results. The only symptom of rent extraction is the lack of lock up provisions for plans offered to top managers, but the absence of these mechanisms is not enough to support this conclusion. In sum, our findings do not show evident traces of misappropriation, and do not support hypothesis 2 .

\section{Insert tables 3, 4, and 5 about here}

Unfortunately, companies do not provide the fair value of equity incentives offered to recipients - and do not state often the number of options and the number of beneficiaries and so it has been impossible to identify the amount of value transferred to recipients with the plan. For this reason, results presented in tables 3, 4, and 5 do not allow us to draw significant conclusions about hypothesis 2. However, the analysis of articles published in newspapers and journals allowed us to find that some Italian companies offered generous equity incentive plans to major shareholders as managers or directors of the corporation. Among the others, we found also two cases that may be potentially considered as symptoms of controlling shareholders' abuse. These examples do not prove that equity incentive plans have been systematically used to distribute a large amount of wealth to controlling shareholders. They showed, instead, that these mechanisms may have been used to this purpose.

The first case regards Pirelli group, a large group operating in cables and tire industries. In September 2000, Pirelli sold its optical fiber division - incorporated in Optical Technologies - to Corning for more than 3 billion dollars (Il Sole 24 Ore, 2000a). The deal has been very profitable for Pirelli, whose capital gain was about 1.4 billion dollars. After the deal, commentators noticed some traces of potential abuse of the controlling shareholder (Il Sole 24 Ore, 2000b). First, the holding company (Camfin) - controlled by Tronchetti Provera 
family - increased its shareholding before the official announcement of the deal that pushed up the value of Pirelli's shares. Second, media and investors discovered - only after the deal had been signed - the existence of an equity incentive plan offering the options to buy $12.5 \%$ of company’s equity to three top managers. The three top managers were the CEO and major shareholder of the company (that received $6 \%$ of the shares thanks to the plan), the CFO (2.5\% of the shares), and the chief of the cable division (4\% of the shares). The capital gains were enormous for Italian standards: they were respectively about 219 million dollars for the CEO, 128 million dollars for the chief of cable divisions, and 80 million dollars for the CFO. The amount of the capital gain and the lack of transparency before the signature of the deal led commentators to question the operation, although there were no legal implications for the subjects involved (Il Sole 24 Ore, 2000b).

The second case regards CIR, a mid-cap financial company controlled by Cofide, another financial listed company. Both companies belong to a pyramidal group controlled by De Benedetti family. The CIR unification has been one of the clearest examples of market abuse before a favorable unification (Bigelli and Mehrotra, 2005). CIR was a dual-class shares company. Non-voting shares represented $22.5 \%$ of the firm's equity. On September 2000 the board proposed a 1:1 coercive unification of voting and non-voting shares, which was approved one month later. In the three days around the announcement date, the voting shares dropped by $6.73 \%$ while non-voting shares gained $6.44 \%$. The majority shareholder took profit of this event both buying non-voting shares, and receiving stock option plans on non-voting shares before the unification. First, during the months of April and May 2000, Cofide had bought CIR non-voting shares and sold CIR voting shares. Second, in 1999, a stock option plan based on non-voting shares was approved by the CIR's board of directors. The first exercise date was set on December 1999, and all board members exercised their stock options on that date. The CEO (a member of the controlling family) exercised his stock 
options for 2 million shares on that date. In March 2000, six months before the unification announcement, the board approved a new stock option plan based on non-voting shares. Unfortunately for the controlling shareholder, the stock market decline in April 2000 (due to the collapse of the Internet bubble) and these new options remained underwater (Bigelli and Mehrotra, 2005). The lack of transparency on the stock option plan before the company's unification led commentators to question the operation, but also in this case there were no legal implications for the subjects involved.

\section{Equity incentive plans and tax rules}

Finally, we tested differences between plans offered in 1998-99 and plans offered in 2004-05. Our results (see table 6) show that (i) the plans offered in the two time periods - characterized by different tax regulations - differ significantly in almost all their characteristics; (ii) the specific features of equity incentive plans generally comply with all the requirements in tax regulations so that fiscal benefits can be accessed. In particular, plans issued in 2004-2005 are characterized by a larger adoption of previously issued shares (sell own shares $=.18$ versus $.09, \mathrm{p}<.10$ ), a larger use of an exercise price offered at market value (market value $=.91$ versus .17, $\mathrm{p}<.001$ ), and a larger involvement of directors (directors $=.40$ versus $.13, \mathrm{p}<001$ ).

Despite the fact that annual reports rarely make specific reference to fiscal advantages, our results show a strong link between fiscal regulations and the use of equity incentive plans. In sum, our results support hypothesis 3. 


\section{DISCUSSION}

We believe our findings contribute to expand the traditional knowledge on reasons behind the adoption of equity incentive plans outside Anglo-Saxon countries, and support a symbolic perspective of corporate governance, according to which the introduction of new governance practices may not imply substantive governance reforms.

\section{The reasons behind the adoption of equity incentive plans}

Three rationales may explain the diffusion and the characteristics of equity incentive plans. They are (i) the optimal contracting view, (ii) the rent extraction view, and (iii) the perceivedcost view. Our results do not support the first and the second rationale, while they are coherent with the third one.

With respect to the first rationale, our results show that the absence of a controlling shareholder does not have a significant impact on the adoption of equity incentive plans. These plans are not extensively used to align shareholders and managers' interests in presence of the separation between ownership and control as it is in the Anglo-Saxon public companies (Jensen and Murphy, 1990). These instruments are, instead, more diffused in larger companies that have superior abilities to introduce complex governance devices - as equity incentive plans - because they employ specialists in accounting, taxation and commercial law (Uchida, 2006). The adoption of these plans by larger companies may be explained also considering that the international labor market is an important driver behind their diffusion (Cheffins and Thomas, 2004), and that this market exerts greater pressure on larger companies. This conclusion is coherent with previous studies on the Italian context showing that, especially in the first period of their adoption, only a small number of plans establish a strong link between employees’ compensation and company performance. Most of the plans 
assign instead a positive supplementary compensation which can vary significantly when there are major fluctuations in share value (Zattoni, 2006).

The second rationale provides a more convincing explanation of why equity incentive plans have become so widespread in Italy and what characteristics these plans have. Unlike the US, where the critical problem of corporate governance is the ease with which managers misappropriate value from shareholders, in Italy (and in many other Continental European countries) the dilemma centers on the structural conflict of interest between majority and minority shareholders (La Porta et al., 1999). A concentrated share structure gives rise to the risk that controlling shareholders take profit of their position to expropriate minority shareholders (Johnson et al., 2000). As we argued before, controlling shareholders of Italian listed companies are usually directors and also top managers of their companies (e.g. Melis, 1999; Molteni, 1997), and have the power to influence the board decision making (Melis, 1999 and 2000). As shareholders, they may approve extremely generous equity incentive plans for themselves as top managers or directors of the firm. Our results did not show a large scale evidence of controlling shareholder's abuse, also because the lack of transparency did not allow understanding all features of the plans. However, we presented two cases of potential abuse indicating that these instruments may have been used to this purpose especially in the first years of their diffusion. The hypothesis of potential rent extraction is supported also by the results of a recent study that analyzed the characteristics of 168 stock option plans implemented in the time frame 2004-2006 by Italian non financial listed companies (Melis, Carta, and Gaia, 2008). Melis, Carta and Gaia conclude, in fact, stating that "... the diffusion of stock option plans in Italian non financial listed companies can hardly be explained by optimal contracting theory" and that "other competing theories, such as rent-extraction theory, seem to provide more powerful explanation of corporate reality...” (Melis et al., 2008: 16). 
The third rationale is the most important in explaining the dissemination and features of these instruments among Italian companies. In this country (and elsewhere) two variables have played a key role in the rise in popularity of these tools: no record of relative costs and tax benefits on income generated from these plans (Hall and Murphy, 2000). As for the first, in Italy there was in that period no legislation requiring that the cost of a plan be recorded on the profit and loss account if options were granted free of charge (as is always the case). Despite the fact that not a single company cites the lack of cost accounting as a reason for adopting these plans, this factor may have facilitated the spread of these instruments in Italy and other countries (Zattoni, 2006). The same is true regarding tax laws: while almost no company indicated fiscal benefits as an impetus for implementing an equity incentive plan, the widespread dissemination of these instruments came about only after strong incentives were integrated into new fiscal regulations (Zattoni, 2006). Our results show that the formal features of these plans respect the requirements set down in fiscal norms in order to access tax benefits, and evolve with the change in the tax law. On the basis of this evidence, our study supports the perceived cost view - and in particular the impact of tax regulation - as the main rationale behind the rise in popularity of these tools.

\section{The diffusion of new governance practices}

A number of studies have examined the diffusion of organizational practices among corporations (e.g. Strang and Soule, 1998; Westphal, Gulati, and Shortell, 1997; Zucker, 1983). The large majority of contributions on the diffusion of new practices implies a binary approach of adoption/non-adoption, and treats the practices themselves as relatively unchanging and uniform. With few exceptions, prior research has focused on the adoption of new practices per se, without considering the adequacy of the instruments with the firm's 
characteristics, or their implications for firms’ stakeholders (Fiss and Zajac, 2004). Our study analyzed, instead, both the diffusion and characteristics of new governance practices.

Our findings suggest that the adoption of equity incentive plans has been a subtle way for decoupling, i.e. maintaining external legitimacy and serving the interests of powerful leaders at the same time (Meyer and Rowan, 1977; Westphal and Zajac, 2001). In particular, the study contributes to explain some neglected aspects of institutional decoupling, i.e. the conditions favoring its appearance and its consequences for the company and the stakeholders (e.g. Westphal and Zajac, 1998 and 2001). About the first issue, our results show that the lack of previous experience with these instruments and the ambiguity implicit in their use (i.e. their apparent shareholder value orientation versus their potential use to extract company value or to reduce labor costs) favored the decoupling process. About its consequences, the results suggest that decoupling happens not only because it is effective for the organization (e.g. Meyer and Rowan, 1977), but also because it serves the interests of powerful corporate leaders (e.g. Westphal and Zajac, 2001).

Our findings are consistent with a symbolic perspective on corporate governance, according to which symbolic actions (i.e. the introduction of equity incentive plans) can engender significant positive stockholder reactions without implying substantive governance reforms (e.g. Fiss and Zajac, 2004; Westphal and Zajac, 1998; Zattoni and Cuomo, 2008). The empirical evidence collected in this study shows that equity incentive plans - due to their implicit ambiguity, the low transparency on their features, and the lack of previous experience in their use - are among the most suitable mechanisms available to Italian controlling shareholders to extract value from the company at the minority shareholders' expense (Bebchuk and Fried, 2006) or to reduce the tax burden on the labor costs (Hall and Murphy, 2003). As such, our findings question the dominant assumption that there is an international convergence of good governance practices (e.g. Gordon and Roe, 2004), and underline that 
the presumed convergence may be more symbolic than substantive (Wetsphal and Zajac, 2001).

\section{Practical implications and limitations}

Equity incentive plans - and especially stock option plans - are means which top managers and majority shareholders may use to expropriate minority shareholders with little transparence and low risk (Bebchuk and Fried, 2006). The risk of misappropriation is very high if - as it happen in Italy and in other countries - public information on these plans does not allow stakeholders to reconstruct all their features.

The best remedy for protecting against this risk lies in shoring up disclosure policies on executive compensation packages, which are typically weak outside the United States (Buck, Shahrim, and Winter, 2004). Requiring firms to make detailed, timely information available before and after issuing equity incentives can be beneficial in terms of enhancing transparency and reducing risks associated with the use of these instruments (Cheffins and Thomas, 2004; Conyon, 2001). In addition, the design process of these plans must be managed cautiously to prevent potential recipients from influencing the features of these mechanisms to their own advantage. This objective can be achieved, for example, by delegating plan design to a compensation committee made up of independent directors, or to independent consultants nominated by this committee (Sykes, 2002). Moreover, the watchdog role of institutional investors is crucial in assuring the respect of the fair treatment of all shareholders (Shleifer and Visnhy, 1997).

Finally, one should ask if it is correct to treat equity incentive plans differently from any other incentive tool, both from accounting and fiscal standpoints (Lee, 2002). The requirement to record the effects of stock option plans according to the fair value method (IFRS2 - share-based payments), and the evolution of tax laws, clearly signal the desire to 
limit or to eliminate the accounting and fiscal advantages that have facilitated the dissemination of these instruments (Zattoni, 2006).

Before concluding, we acknowledge the limitations of our study. First, we focused on Italy, because we believe it is particularly interesting investigating the phenomenon in this country. In fact, both the lack of equity incentive plans until the end of the '90s and the presence of large blockholders make Italy a particularly interesting setting. However, we acknowledge that corporate governance practices are in some way country specific, and so we invite scholars to collect evidence on the diffusion and the characteristics of equity incentive plans in other countries. The second main limitation of the study is the lack of complete data on the characteristics of equity incentive plans adopted by Italian companies. This is due to the incompleteness of the public information on these plans. We hope future studies will fill this gap collecting richer and more complete data either in Italy - if the information will be disclosed - or in other countries. We also hope that complete or richer information on these plans will allow scholars to make a robust analysis of the relationship between their characteristics and companies’ ones.

\section{CONCLUSIONS}

This article investigated the diffusion and the characteristics of equity incentive plans adopted by Italian listed companies. Evidence from our study indicates that the diffusion of equity incentive plans and the evolution of their characteristics may be explained by the perceivedcost view, and to a less extent by the rent extraction view. In this sense, the study expands traditional understanding of institutional decoupling, providing more empirical evidence on its antecedents and consequences. About the first issue, our results underline that new governance practices - especially if ambiguous, not well known before, and with an implicit incentive to create value - may be used by powerful actors to misappropriate other 
stakeholders or to pursue other advantages (i.e. to have access to tax benefits). About the second issue, our findings show that decoupling may not only produce positive effects for the organization, but may also benefit some powerful corporate leaders at the expense of other stakeholders. . 


\section{References}

Alvarez Perez, D. and Neira Fontela, E (2005) Stock option plans for CEO compensation, Corporate Ownership and Control, 3 (1): 88-100.

Autuori, L. (2001) Gli aspetti giuridici dei piani di stock option. In Airoldi, G. and Zattoni, A. (eds.), Piani di stock option. Milano: Egea.

Barca, F. and Becht, M. (eds.) (2001) The Control of Corporate Europe. Oxford, Oxford University Press.

Bebchuk, L.A., Fried, J. and Walker, D. (2002) Managerial Power and Rent Extraction in the Design of Executive Compensation, University of Chicago Law Review, 69: 751-846.

Bebchuk, L.A. and Fried, J. (2006) Pay Without Performance: Overview of the Issues, Academy Management Perspectives, 1: 5-24.

Berle, A. and Means, G. (1932) The Modern Corporation and Private Property. New York: MacMillan.

Bernhardt, W. (1999) Stock Options for or Against Shareholder Value?, Corporate Governance: An International Review, 7, 123-135.

Bianchi, M. and Enriques, L. (2005) Corporate Governance in Italy After the 1998 Reform: What Role for Institutional Investors?, Corporate Ownership and Control, 2 (4): 11-31.

Bianchi, M., Bianco, M. and Enriques, L. (2001) Pyramidal Groups and the Separation Between Ownership and Control in Italy. In Barca, F. and Becht, M. (eds.), The Control of Corporate Europe. Oxford: Oxford University Press.

Bianco, M. (2001) Italy. In Gugler, K. (ed.), Corporate Governance and Economic Performance. Oxford: Oxford University Press.

Bigelli, M. and Mehrotra, V. (2005) Private and social benefits in dual class share unification - Evidence from Italy, working paper. 
Brandes, P., Dharwadkar, R. and Lemesis, V. (2003) Effective Employee Stock Option Design: Reconciling Stakeholder, Strategic, and Motivational Issues, Academy of Management Executive, n.1, 77-93.

Buck, T., Shahrim, A. and Winter, S. (2004) Executive Stock Options in Germany: The Diffusion or Translation of US-Style Corporate Governance?, Journal of Management \& Governance, 8 (2), 173-186.

Certo, S.T., Daily, C.M., Cannella, A.A. and Dalton, D.R. (2003) Giving money to get money: How CEO stock options and CEO equity enhance IPO valuations, Academy of Management Journal, 46 (5): 643-653.

Cesarini, F. (1986) Le offerte di azioni ai dipendenti: aspetti economici e tecnici nella recente esperienza delle società quotate italiane, Rivista delle società, November-December.

Cheffins, B.R. (2003) Will Executive Pay Globalise Along American Lines?, Corporate Governance: An International Review, 11 (1), 8-24.

Cheffins, B.R. and Thomas, R.S. (2004) The globalization (Americanization?) of Executive Pay, Berkeley Business Law Journal, Fall, 233-289.

Conyon, M. J. and Murphy, K.J. (2000) The Prince and the Pauper? CEO pay in the United States and the United Kingdom, Economic Journal, 110: 640-671.

Conyon, M.J. (2001) The Disclosure of UK Boardroom Pay: The March 2001 DTI Proposal, Corporate Governance: An International Review, 9 (4), 276-285.

Dyck, A. and Zingales, L. (2004) Private benefits of control: An international comparison, Journal of Finance, LIX (2): 537-600.

Eaton, J. and Rosen, H.S. (1983) Agency, delayed compensation, and the structure of executive remuneration, Journal of Finance, 38: 1489-1505.

Faccio, M. and Lang, L. (2002) The ultimate ownership of Western European corporations, Journal of Financial Economics, 65 (3): 365-395. 
Fama, E. and Jensen, M. (1983) Separation of ownership and control, Journal of Law and Economics, 26: 301-325.

Financial Accounting Standards Board (FASB) (2004) FASB Statement No. 123 (revised), Share-Based Payment (FAS-123R).

Fiss, P.C. and Zajac, E.J. (2004) The diffusion of ideas over contested terrain: The (non)adoption of a shareholder value orientation among German firms, Administrative Science Quarterly, 49, 501-534.

Gianfrate, G. (2007) What Do Shareholders' Coalitions Really Want? Evidence from Italian voting trusts, Corporate Governance: An International Review, 15 (2), 122-132.

Gordon, J.N. and Roe, M.J. (eds.) (2004) Convergence and persistence in corporate governance. Cambridge: Cambridge University Press.

Gualtieri P. (1993) Dirigenti e capitali d’impresa: i piani di “stock option”. Bologna: Il Mulino.

Hall, B.J. (2000) What You Need to Know About Stock Options, Harvard Business Review, March-April, 121-129.

Hall, B.J. and Liebman, J.B. (1998) Are CEO Really Paid Like Bureaucrats?, Quarterly Journal of Economics, 113 (3): 653-691.

Hall, B.J. and Murphy, K.J. (2003) The Trouble with Stock Options, Journal of Economic Perspectives, 3: p49-70.

Hansmann, H. (1988) “The ownership of the firm”, Journal of Law, Economics, and Organization, 4: 267-304.

Hambrick, D.C. (2005) Top management teams, Blackwell Encyclopaedic Dictionary of Organizational Behavior: 399.

Hart, O. (1995) Corporate Governance: Some Theory and Implications, The Economic Journal, 105: 678-689. 
Il Sole 24 Ore (2000a) Pirelli cede tlc in fibra per 6.750 mld, 27 September 2000.

Il Sole 24 Ore (2000b) Assogestioni chiama Consob sul caso Pirelli, 25 October 2000.

International Accounting Standard Board (2004) IFRS 2 - Share-based Payments. London: IASCF.

Jensen, M. and Murphy, K.J. (1990) CEO Incentives - It's Not How Much You Pay, But How, Harvard Business Review, May-June, 138-153.

Jensen, M.C. and Meckling, W.H. (1976) Theory of the Firm: Managerial Behavior, Agency Costs, and Capital Structure, Journal of Financial Economics, 3: 305-360.

Jick, T.D. (1979) Mixing qualitative and quantitative methods: Triangulation in action, Administrative Science Quarterly, 24: 602-611.

Johnson, S., La Porta, R., Lopez-de-Silanes, F. and Shleifer, A. (2000) Tunneling, American Economic Review, 90 (2), Papers and Proceedings of the One Hundred Twelfth Annual Meeting of the American Economic Association, 22-27.

La Porta, R., Lopez-de-Silanes, F. and Shleifer, A. (1999) Corporate Ownership Around the World, Journal of Finance, 54 (2), 471-517.

Lee, P. (2002) Not Badly Paid But Paid Badly, Corporate Governance - An International Review, 10 (2), 69-74.

Marchica, M.T. and Mura, R. (2005) Direct and Ultimate Ownership Structures in the UK: An Intertemporal Perspective over the Last Decade, Corporate Governance: An International Review, 13(1): 26-45.

Melis, A., Carta, S. and Gaia, S. (2008) Shareholder rights and director remuneration in blockholder-dominated firms. Why do Italian firms use stock options?, working paper presented at the conference on "Shareholder Rights, Shareholder Voting and Corporate Performance, University of Cagliari, 21-22 March 2008. 
Melis, A. (1999) Corporate governance - Un’analisi empirica della realtà italiana in un’ottica europea. Torino: Giappichelli.

Melis, A. (2000) Corporate Governance in Italy, Corporate Governance: An International Review, 8 (4): 347-355.

Meyer, J.W. and Rowan, B. (1977) Institutional organizations: Formal structure as myth and ceremony, American Journal of Sociology, 83: 340-363.

Molteni, M. (1997) I sistemi di corporate governance nelle imprese italiane di medie e grandi dimensioni. In Molteni, M. (ed.), I sistemi di corporate governance nelle grandi imprese italiane. Milano: Egea.

Mosca, C. and Angelillis, A. (2008) Takeover Bids in Europe: Does the 13th Directive Lead to Convergence or Enhance Divergence? A First Answer in the Light of Initial Experiences, working paper presented at the 6th International Conference on Corporate Governance: The Evolution of Corporate Governance, Centre for Corporate Governance Research, Birmingham 30th June.

Murphy, K. (2002) Explaining Executive Compensation: Managerial Power versus the Perceived Cost of Stock Options, University of Chicago Law Review, 69: 847-869.

Nagaoka, S. (2005) Determinants of the Introduction of Stock Options by Japanese Firms: Analysis from the Incentive and Selection Perspectives, Journal of Business, 78 (6): 22892315.

Nenova, T. (2003) The value of corporate voting rights and control: A cross-country analysis, Journal of Financial Economics, 68(3), 325-351.

Oliver, C. (1992) The antecedents of de-institutionalization, Organization Studies, 13, 563588.

Rodrick, S.S. (ed.) (2000) The stock options book. Oakland: NCEO. 
Sanders, G. and Tuschke, A. (2007) The adoption of institutionally contested organizational practices: The emergence of stock option pay in Germany, Academy of Management Journal, 50 (1): 33-56.

Shleifer, A. and Visnhy, R. (1997) A survey of corporate governance, Journal of Finance, 52: 737-783.

Strang, D. and Soule, S.A. (1998) Diffusion in organizations and social movements: From hybrid corn to poison pills, Annual Review of Sociology, 24: 265-290.

Sykes, A. (2002) Overcoming Poor Value Executive Remuneration: Resolving the Manifest Conflicts of Interests, Corporate Governance: An International Review, 10 (4), 256-260.

Towers Perrin (2000) Worldwide Total Remuneration Study.

Towers Perrin (2005) Equity incentives around the world.

Uchida, K. (2006) Determinants of stock option use by Japanese companies, Review of Financial economics, 15: 251-269.

Westphal, J.D. and Zajac, E.J. (1998) The symbolic management of stockholders: Corporate governance reforms and shareholder reactions, Administrative Science Quarterly, 43(1): 127-153.

Westphal, J.D. and Zajac, E.J. (2001) Decoupling policy from practice: The case of stock repurchase plans, Administrative Science Quarterly, 46: 202-228.

Westphal, J.D., Gulati, R. and Shortell, S.M. (1997) Customization or conformity. An institutional and network perspective on the content and consequences of TQM adoption. Administrative Science Quarterly, 42: 366-394.

Zattoni, A. (1999) The Structure of Corporate Groups: The Italian Case, Corporate Governance: An International Review, January, 38-48.

Zattoni, A. (2006) Assetti proprietari e corporate governance. Milano: Egea. 
Zattoni, A. (2007) Stock Incentive Plans in Europe: Empirical Evidence and Design Implications, Corporate Ownership and Control, 4 (4): 56-64.

Zattoni, A. and Cuomo, F. (2008) Why adopt codes of good governance? A comparison of institutional and efficiency perspectives, Corporate Governance: An International Review, $16(1): 1-15$

Zucker, L.G. (1983) Organizations as institutions. In Bacharach S.B. (ed.) Perspectives in organizational sociology. Theory and Research. ASA Series, Vol 2 Greenwich, CT JAI Press. 
Table 1: The main characteristics of Italian listed companies at the end of 1999 and at the end of 2005

\begin{tabular}{|c|c|c|c|c|c|c|}
\hline & \multicolumn{3}{|c|}{ Sample 1999} & \multicolumn{3}{|c|}{ Sample 2005} \\
\hline & $\begin{array}{l}\text { Companies } \\
\text { with plans }\end{array}$ & $\begin{array}{c}\text { Companies } \\
\text { without } \\
\text { plans }\end{array}$ & $\begin{array}{c}\text { All } \\
\text { companies }\end{array}$ & $\begin{array}{l}\text { Companies } \\
\text { with plans }\end{array}$ & $\begin{array}{c}\text { Companies } \\
\text { without } \\
\text { plans }\end{array}$ & $\begin{array}{c}\text { All } \\
\text { companies }\end{array}$ \\
\hline Number of companies & 60 & 178 & 238 & 57 & 193 & 250 \\
\hline $\begin{array}{l}\text { Industry } \\
\text { - manufacturing } \\
\text { - services } \\
\text { - financial }\end{array}$ & $\begin{array}{l}27 \\
15 \\
18\end{array}$ & $\begin{array}{l}82 \\
21 \\
75\end{array}$ & $\begin{array}{r}109 \\
36 \\
93\end{array}$ & $\begin{array}{l}20 \\
17 \\
20\end{array}$ & $\begin{array}{l}76 \\
61 \\
56\end{array}$ & $\begin{array}{l}96 \\
78 \\
76\end{array}$ \\
\hline $\begin{array}{l}\text { Ownership structure } \\
\text { - controlling } \\
\text { shareholder } \\
\text { - ultimate family } \\
\text { - ultimate State } \\
\text { - } \text { syndicate agreements }\end{array}$ & $\begin{array}{r}45 \\
27 \\
8 \\
21\end{array}$ & $\begin{array}{r}133 \\
92 \\
9 \\
49\end{array}$ & $\begin{array}{r}178 \\
119 \\
17 \\
70\end{array}$ & $\begin{array}{r}36 \\
32 \\
4 \\
19\end{array}$ & $\begin{array}{r}154 \\
120 \\
15 \\
39\end{array}$ & $\begin{array}{r}190 \\
152 \\
19 \\
58\end{array}$ \\
\hline $\begin{array}{l}\text { Market capitalization } \\
\text { (mean in million euro) }\end{array}$ & 8,721 & 1,114 & 3,000 & 4,648 & 2,091 & 2,681 \\
\hline $\begin{array}{l}\text { Companies listed in the } \\
\text { previous five years }\end{array}$ & 22 & 58 & 80 & 26 & 67 & 93 \\
\hline
\end{tabular}

Sources of data: (i) Italian Stock Exchange for industry and market capitalization of listed companies; (ii) Consob for ownership structure of listed companies; (iii) companies' annual reports for the adoption of equity incentive plans. 
Table 2. Logit models on the relationship between ownership structure and equity incentive plan's adoption

\begin{tabular}{lcccc}
\hline & \multicolumn{2}{c}{$1998-1999$} & \multicolumn{2}{c}{$2004-2005$} \\
\hline Constant & Coefficient & Std Error & Coefficient & Std Error \\
Absence of a controlling shareholder & $-5.99 * * *$ & .95 & $-4.24 * * *$ & .82 \\
Ultimate family & -.11 & .46 & .54 & .45 \\
Ultimate State & .31 & .46 & .33 & .45 \\
Syndicate agreements & .01 & .79 & -.50 & .80 \\
Service industry & .39 & .40 & .56 & .38 \\
Financial industry & -.24 & .55 & -.18 & .43 \\
Log mkt cap & $-1.24^{*}$ & .49 & -.21 & .45 \\
Listed in the previous 5 years & $1.78^{* * *}$ & .29 & $.80^{* *}$ & .26 \\
Plans in 1998-1999 & .32 & .38 & $.75^{*}$ & .38 \\
Number of observations & - & -67 & .45 \\
$\chi^{2}$ & \multicolumn{2}{c}{59} & & 57 \\
\hline
\end{tabular}

${ }^{\dagger} p<.10 ; * p<.05 ; * * p<.01 ; * * * p<.001$. 
Table 3. T-tests for difference-of-means between plans offered to less than 3 employees and all other plans ${ }^{\mathrm{vi}}$

\begin{tabular}{|c|c|c|c|c|c|c|c|}
\hline \multicolumn{2}{|c|}{ Characteristics of equity incentive plans } & \multicolumn{3}{|c|}{$\begin{array}{c}\text { Plans offered to less than } 3 \\
\text { employees }\end{array}$} & \multicolumn{3}{|c|}{ All other plans } \\
\hline & & Mean & $\begin{array}{c}\text { Std } \\
\text { Error }\end{array}$ & $\mathrm{N}^{\circ}$ & Mean & Std Error & $\mathrm{N}^{\circ}$ \\
\hline \multirow[t]{2}{*}{ 1) Content } & Options & $1.00 * * *$ & .00 & 12 & .84 & .03 & 168 \\
\hline & Shares & $.00 * * *$ & .00 & 12 & .17 & .03 & 166 \\
\hline \multirow[t]{2}{*}{ 2) Method } & Capital increase & .83 & .11 & 12 & .88 & .03 & 150 \\
\hline & Sell own shares & .17 & .11 & 12 & .13 & .03 & 150 \\
\hline \multirow[t]{2}{*}{ 3) Price } & Market value & .67 & .14 & 12 & .54 & .04 & 143 \\
\hline & Lower than market value & .33 & .14 & 12 & .46 & .04 & 143 \\
\hline \multirow[t]{2}{*}{ 4) Parameters } & Individual & .33 & .21 & 6 & .19 & .05 & 73 \\
\hline & Company & $1.00 * * *$ & .00 & 7 & .68 & .05 & 73 \\
\hline \multirow[t]{3}{*}{ 5) Goal } & Incentive & .89 & .11 & 9 & .94 & .02 & 99 \\
\hline & Retain & .59 & .17 & 9 & .55 & .05 & 99 \\
\hline & Identity & $.00 * *$ & .00 & 9 & .10 & .03 & 99 \\
\hline \multirow[t]{2}{*}{ 6) Time horizon } & Entire plan & 4.89 & .65 & 9 & 4.80 & .20 & 138 \\
\hline & Vesting period & 1.50 & .22 & 10 & 1.92 & .10 & 112 \\
\hline 7) Lock-up & & $.00 * * *$ & .00 & 3 & .83 & .19 & 39 \\
\hline
\end{tabular}

${ }^{\dagger} p<.10 ; * p<.05 ;{ }^{* *} p<.01 ; * * * p<.001$. 
Table 4. T-tests for difference-of-means between plans offered to less than 10 employees and all other plans

\begin{tabular}{|c|c|c|c|c|c|c|c|}
\hline \multicolumn{2}{|c|}{ Characteristics of equity incentive plans } & \multicolumn{3}{|c|}{$\begin{array}{c}\text { Plans offered to less than } 10 \\
\text { employees }\end{array}$} & \multicolumn{3}{|c|}{ All other plans } \\
\hline & & Mean & Std Error & $\mathrm{N}^{\circ}$ & Mean & Std Error & $\mathrm{N}^{\circ}$ \\
\hline \multirow[t]{2}{*}{ 1) Content } & Options & .94 & .06 & 17 & .84 & .03 & 163 \\
\hline & Shares & .06 & .06 & 17 & .17 & .03 & 161 \\
\hline \multirow[t]{2}{*}{ 2) Method } & Capital increase & .88 & .08 & 16 & .88 & .03 & 146 \\
\hline & Sell own shares & .13 & .08 & 16 & .14 & .03 & 146 \\
\hline \multirow[t]{2}{*}{ 3) Price } & Market value & .56 & .13 & 16 & .55 & .04 & 139 \\
\hline & Lower than market value & .44 & .13 & 16 & .45 & .04 & 139 \\
\hline \multirow[t]{2}{*}{ 4) Parameters } & Individual & .29 & .18 & 7 & .19 & .05 & 72 \\
\hline & Company & $1.00 * * *$ & .00 & 8 & .68 & .05 & 72 \\
\hline \multirow[t]{3}{*}{ 5) Goal } & Incentive & .85 & .10 & 13 & .95 & .02 & 95 \\
\hline & Retain & .46 & .14 & 13 & .58 & .05 & 95 \\
\hline & Identity & $.00 * *$ & .00 & 13 & .11 & .03 & 95 \\
\hline \multirow[t]{2}{*}{ 6) Time horizon } & Entire plan & 4.93 & .67 & 14 & 4.79 & .21 & 133 \\
\hline & Vesting period & 1.78 & .26 & 14 & 1.90 & .10 & 108 \\
\hline 7) Lock-up & & $.00 * * *$ & .00 & 4 & .85 & .19 & 38 \\
\hline
\end{tabular}

${ }^{\dagger} p<.10 ;{ }^{*} p<.05$; $^{* *} p<.01$; $^{* * *} p<.001$. 
Table 5. T-tests for difference-of-means between plans offered to directors and all other plans

\begin{tabular}{lllrrrrr}
\hline \multicolumn{2}{l}{ Characteristics of equity incentive plans } & \multicolumn{3}{c}{ Plans offered to directors } & \multicolumn{3}{c}{ All other plans } \\
\hline \multirow{2}{*}{ 1) Content } & & Mean & Std Error & $\mathrm{N}^{\circ}$ & Mean & Std Error & $\mathrm{N}^{\circ}$ \\
& Options & $.96^{*}$ & .03 & 49 & .81 & .04 & 122 \\
\multirow{3}{*}{ Method } & Shares & $.04^{*}$ & .03 & 47 & .20 & .04 & 122 \\
& Capital increase & $.74^{* *}$ & .07 & 38 & .91 & .03 & 117 \\
& Sell own shares & $.26^{* *}$ & .07 & 38 & .10 & .03 & 117 \\
& Market value & $.80^{* * *}$ & .06 & 41 & .44 & .05 & 107 \\
4) Parameters & Lower than market value & $.20^{* * *}$ & .06 & 41 & .56 & .05 & 107 \\
& Individual & .17 & .08 & 23 & .20 & .05 & 55 \\
5) Goal & Company & $.91^{*}$ & .06 & 23 & .64 & .06 & 56 \\
& Incentive & .96 & .04 & 28 & .93 & .03 & 75 \\
& Retain & .46 & .10 & 28 & .60 & .06 & 75 \\
6) Time horizon & Identity & .14 & .07 & 28 & .08 & .03 & 75 \\
& Entire plan & 4.83 & .34 & 40 & 4.90 & .25 & 99 \\
7) Lock-up & Vesting period & 2.08 & .17 & 42 & 1.78 & .12 & 69 \\
& & .88 & .48 & 8 & .76 & .20 & 32
\end{tabular}

${ }^{\dagger} p<.10 ; * p<.05 ; * * p<.01 ; * * * p<.001$. 
Table 6. T-tests for difference-of-means between plans issued in 1998-99 and plans issued in 2004-05 ${ }^{\text {vii }}$

\begin{tabular}{|c|c|c|c|c|c|c|c|}
\hline \multicolumn{2}{|c|}{ Characteristics of equity incentive plans } & \multicolumn{3}{|c|}{ Plans issued in 1998-1999 } & \multicolumn{3}{|c|}{ Plans issued in $2004-2005$} \\
\hline & & Mean & Std Error & $\mathrm{N}^{\circ}$ & Mean & Std Error & $\mathrm{N}^{\circ}$ \\
\hline \multirow{2}{*}{ 1) Content } & Options & $.68 * * *$ & .05 & 80 & .99 & .01 & 101 \\
\hline & Shares & $.34 * * *$ & .05 & 80 & .01 & .01 & 98 \\
\hline \multirow[t]{3}{*}{ 2) Recipients } & Managers & $.85 * *$ & .04 & 80 & .65 & .05 & 98 \\
\hline & Employees & $.13^{* *}$ & .04 & 80 & .28 & .04 & 99 \\
\hline & Directors & $.13^{* * *}$ & .04 & 80 & .40 & .05 & 99 \\
\hline \multirow[t]{2}{*}{ 3) Method } & Capital increase & .91 & .03 & 79 & .84 & .04 & 83 \\
\hline & Sell own shares & $.09^{\dagger}$ & .03 & 79 & .18 & .04 & 83 \\
\hline \multirow[t]{2}{*}{ 4) Price } & Market value & $.17 * * *$ & .04 & 76 & .91 & .03 & 79 \\
\hline & Lower than market value & $.83 * * *$ & .04 & 76 & .09 & .03 & 79 \\
\hline \multirow[t]{2}{*}{ 5) Parameters } & Individual & $.30^{\dagger}$ & .08 & 33 & .13 & .05 & 46 \\
\hline & Company & .74 & .08 & 34 & .70 & .07 & 46 \\
\hline \multirow[t]{3}{*}{ 6) Goal } & Incentive & .93 & .03 & 56 & .94 & .03 & 52 \\
\hline & Retain & $.43^{* *}$ & .07 & 56 & .71 & .06 & 52 \\
\hline & Identity & .09 & .04 & 56 & .10 & .04 & 52 \\
\hline \multirow[t]{2}{*}{ 7) Time horizon } & Entire plan & $4.07 * * *$ & .27 & 61 & 5.33 & .26 & 86 \\
\hline & Vesting period & $1.55^{*}$ & .18 & 36 & 2.02 & .11 & 86 \\
\hline
\end{tabular}

${ }^{\dagger} p<.10 ; * p<.05 ; * * p<.01 ; * * * p<.001$. 


\section{Biography}

Alessandro Zattoni is Professor of Management at Parthenope University of Naples and Professor of Strategic Management and Corporate Governance at SDA Bocconi School of Management. His main interest of research is corporate governance, with a focus on board of directors, codes of good governance, pyramidal groups, and equity incentive plans.

Alessandro Minichilli is Assistant Professor at Bocconi University in Milan, where he received his Ph.D. in Business Administration and Management. His research interests are in the area of corporate governance, with a focus on the behavioural perspective on boards of directors. He is also interested in family business, and top management teams' impact on corporate performance. 


\section{Notes}

i Equity incentive plans are usually classified in two broad categories: 1) stock option plans, in which the recipient has the option to buy or subscribe company stocks; 2) non stock option plans, which involve employee rewards (either stocks or cash), again, linked to the value of the company's stock (Rodrick, 2000). Trying to avoid confusion with similar concepts and terms, in this article we used the following definitions: (i) equity incentive plans to indicate both stock option and non stock options plans; (ii) stocks or shares to define equity shares, i.e. shares of ownership in a corporation; (iii) stock option plans to indicate plans in which the recipients have the option to buy or subscribe company stocks; (iv) stock granting plans to indicate plans in which the recipients receive company stocks.

ii The white paper of the Ministry of Industry and Foreign Commerce states that a stock option plan "is useful both to attract management in the first phases of firm life cycle, and to let employees participate to the distribution of the firm value they contributed to create" (Ministero dell'Industria e del Commercio Estero, 2000, 35). The Italian code of good governance states, instead, in principle 8.2 that: “... the board of directors, in defining the compensation policies for CEOs, should establish that part of their pay is tied to the firm economic performance and, eventually, to the attainment of objectives defined ex ante by the board”.

iii The new legislation, which took effect on 1 January 2000, eliminated the tax exemption on the shares received through an equity incentive plan and imposed the recipients to pay $12.5 \%$ on the capital gain. Also with the new rule, Italian tax law continued to favor the dissemination of equity incentive plans because at the time of sale of stocks received through them, the recipient was required to pay $12.5 \%$ of any surcharge, when applicable, equal to the difference between the sale price and the "normal" value (market value in the case of a listed company) when stocks were purchased (Autuori, 2001).

iv The term ownership structure may indicate both control rights and cash-flow rights (e.g. Hansmann, 1988). In this article, we used the term "ownership structure" to indicate "the distribution of rights related to capital". This choice is valid if we assume that companies follow the rule "one share-one vote". We think this may be the case because (i) we did not consider explicitly the issue of the separation between ownership and control, (ii) we measured direct ownership and not ultimate ownership that may present a much higher divergence between control and cash-flow rights (e.g. Marchica and Mura, 2005), (iii) Italian listed companies have strongly reduced their use of dual class shares along the time (Zattoni, 2006).

${ }^{\mathrm{v}}$ We measured the absence of a controlling shareholder using also the threshold of 20 per cent. The results of the analysis using this variable are almost identical to that one presented in table 2. For this reason we decided to not report them in the text.

vi The column " $\mathrm{N}$ " presents the number of plans considered respectively in the two preceding columns.

vii The characteristics of equity incentive plans that are relevant for the analysis of the impact of changes in tax law are: (i) directors as recipient category, (ii) sell own shares as technical method, and (iii) market value as price of issuance of stocks. 